Hepatitis-Associated Improvement of Anemia in an Anephric Patient without Elevation of Serum Ervthropoietin Level

\begin{tabular}{|l|l|l|}
\hline J.F. & Navarro \\
\hline J.L. & Teruel \\
\hline J.J. & Villafruela \\
\hline J. & Ortuño \\
\hline
\end{tabular}

Department of Nephrology, Hospital Ramón y Cajal, Madrid, Spain

J.F. Navarro, MD, Department of Nephrology, Hospital Ramón y Cajal, E-28034 Madrid (Spain)

Chronic hepatitis $(\mathrm{HCV}+)$

rHuEPO

In August 1990, a chronic nontransfu-sional hepatitis with positive antibody to hepatitis $\mathrm{C}$ virus was observed with a simultaneous increase in the hemoglobin concentration to $120-130 \mathrm{~g} / \mathrm{l}$, and the EPO dosage was decreased to 3,000 IU/week intravenously. The serum EPO concentration (125I-EPO

Dear Sir,

In the adult, $90 \%$ of erythropoietin (EPO) is produced by the kidney. The alteration of this endocrine renal function is the main cause of anemia in patients with end-stage renal disease [1]. The most important extrare-nal source of EPO is the liver, but the contribution of hepatic EPO to adult erythro-poiesis is minor since EPO levels are very low in anephric patients [2].

In 1971, Kolk-Verger et al. [3] described a significant reduction of anemia in 11 hemodi-alysis patients during an episode of liver cy-tolisis. Similar findings were observed by other authors $[4$, 5].

Brown et al. [6] reported an important increase in serum EPO in an uremic patient with hepatitisassociated elevation of hemoglobin concentration. Elevated serum EPO levels measured with specific radioimmu-noassay were later reported during these episodes of amelioration of anemia concurrently with liver injury [7]. At the moment, this improvement in erythropoiesis is attributed to an increase in the hepatic synthesis of EPO by regenerating hepatocytes [5]. We have observed the amelioration of anemia in an enephric dialysis patient who concurrently showed chronic hepatitis without increase in the serum EPO concentration.

In July 1987, a 56-year-old woman bine-phrectomized for kidney carcinoma began hemodialysis. During the first 18 months, severe anemia was observed and transfusion of 2 packed red blood cells per month was necessary to maintain hemoglobin level between 60 and 70 g/l. In February 1989, recom-binant human EPO (rHuEPO) was introduced (12,000 IU/week intravenously) and new transfusions were not necessary, with stabilization of hemoglobin around $100 \mathrm{~g} / 1$ (fig-1).

\title{
\IIIII/2B PRBC
}

130120110100

$908070 \mathrm{H} 60$ 
XII

\section{IV VI VIII X XII II IV VI $<$}

Months

Fig. 1. Evolution of hemoglobin $(\mathrm{Hb})$ level and seric EPO concentration. PRBC $=$ Packed red blood cells.

COATRIA BIOMENEUX, France) was 3.2 IU/1 (serum EPO concentration in our nonanephric patients undergoing hemodialysis was $7.8 \pm 4.7 \mathrm{IU} / 1$; mean $\pm \mathrm{SD}$ ). This measurement was made in a blood sample obtained before the first dialysis of the week ( $68 \mathrm{~h}$ after the last dosis of $\mathrm{rHuEPO})$; at that

(C) 1993 S.KargerAG, Basel 0028-2766/93/

0653-0495S2.75/0

moment all serum EPO detected by radioim-munoassay has an endogenous origin [8].

In March 1991, the patient presented digestive bleeding, and tumoral relapse was detected with infiltration of the colon and left iliac vessels. At that time, EPO treatment was discontinued.

Removal of tumoral mass was made and a partial resection of sigmoid colon was needed. In the postoperative period, a rupture of the left iliac artery occurred and a vascular bypass was made. Between March and July 1991, transfusion of 28 packed red blood cells was necessary. When hemor-rhagic complications were resolved, a sponta-

neous increase in hemoglobin values was observed. Fifteen months after suspension of EPO, hemoglobin was stable around $110 \mathrm{~g} / \mathrm{l}$. Repeated serum EPO measurements showed values lower than the average level in our patients undergoing hemodialysis. There were no signs of local tumoral relapse or metastatic extension.

This case shows the improvement of anemia in an anephric patient concurrently with an episode of hepatitis without increase in serum EPO levels. There were no changes in factors which might influence erythropoiesis such as the frequency or duration of dialysis,

levels of creatinine or urea, the vitamin or protein intake and the parathyroid hormone level. In dialysis patients, no correlation has been found between immunoreactive EPO and the severity of anemia [9]. Recent findings showed that several serum peptides such as insulin-like growth factor I can have an ery-thropoietic activity in this population [10]. This suggests that factors other than EPO probably play a role in regulating erythropoiesis, and regenerating the liver can be the source of these substances.

\section{References}

Eschbach JW: The anemia of chronic renal failure. Pathophysiology and the effect of recombinant erythropoietin. Kidney Int 1989;35: 134-138.

Cotes PM: Immunoreactive erythropoietin in serum. Br J Haematol 1982;50:427-438.

Kolk-Verger AJ, Bosh E, Van Leeuwen AM: Influence of serum hepatitis on hemoglobin level in patients on regular hemodialysis. Lancet 1971;i:526-528. 
Coleman JC, Eastwood JB, Curtis JR, Fox RA, Edwards M: Hepatitis and epidemic hepatitisassociated antigen (EHAA) in a hemodialysis patient after viral or toxic hepatic cytolisis. Br J Urol 1972;44:194-201.

Simon P, Meyrier A, Tanquerel T, Ang K: Improvement of anaemia in haemodialysis patients after viral or toxic cytolysis. BMJ 1980; 280:892-898.

Brown S, Caro J, Erslev A, Murray T: Spontaneous increase in erythropoietin and hematocrit value associated with transient liver enzyme abnormalities in an anephric patient undergoing hemodialysis. Am J Med 1980;68:280-284.

Klassen D, Spivak J: Hepatitis-related hepatic erythropoietin production. Am J Med 1990; 89: 684-686.

Halstenson C, Macres M, Katz S, Schnieders J, Watanabe M, Sobota J, Abraham P: Comparative pharmacokinetics and pharmacodyna-mics of epoetin alfa and epoetin beta. Clin Pharmacol Ther 1991;50:702-712.

Walle AJ, Wong GY, demons GK, Garcia JF, Niedermayer W: Erythropoietin-hematocrit feedback circuit in the anemia of end-stage renal disease. Kidney Int 1987;31:1205-1209.

10 Ureña P, Bonnardeaux A, Kai-Uwe E, Kurtz A, Drüeke TB: Insulin-like growth factor I: A modulator of erythropoietin in uraemic patients? Nephrol Dial Transplant 1992; 7:40^4.

496

Navarro/Teruel/Villafruela/Ortuño

Hepatitis-Associated Improvement of Anemia 